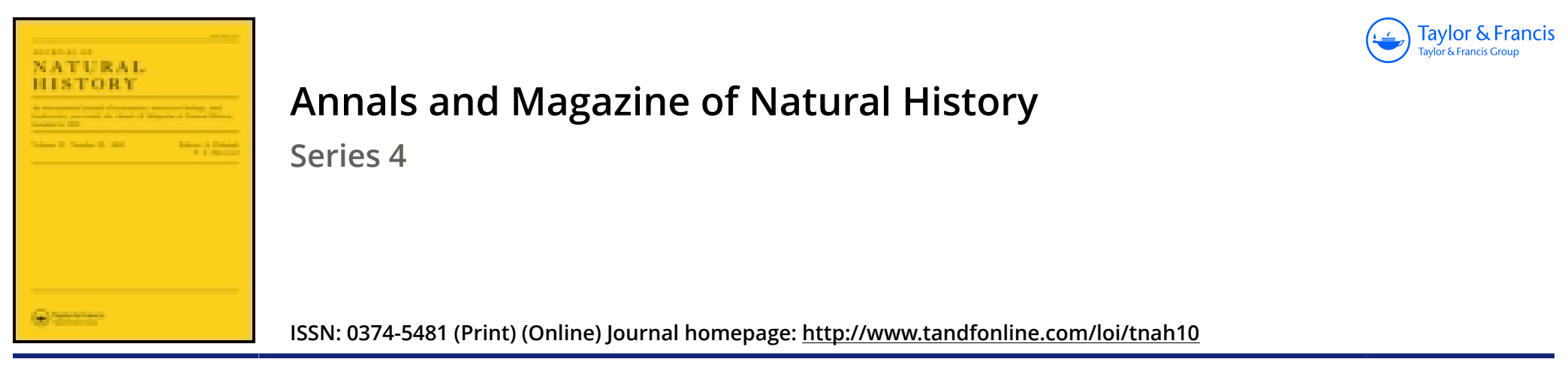

\title{
XXIV.-On a Melobesian form of Foraminifera (Gypsina melobesioides, mihi); and further observations on Carpenteria monticularis
}

\section{H.J. Carter F.R.S.}

To cite this article: H.J. Carter F.R.S. (1877) XXIV.-On a Melobesian form of Foraminifera (Gypsina melobesioides, mihi); and further observations on Carpenteria monticularis, Annals and Magazine of Natural History, 20:117, 172-176, DOI: $10.1080 / 00222937708682220$

To link to this article: http://dx.doi.org/10.1080/00222937708682220

曲 Published online: 13 Oct 2009.

Submit your article to this journal $\pi$

Џll Article views: 2

Q View related articles $\triangle$

Citing articles: 1 View citing articles 
of blue-black. The young had the bare skin yellowish red, without any admixture of blue. The measurements given by Prof. Bocage in the P.Z. S. 1873 , p. 702, show that his examples are larger than the $B$. pyrrhops.

The four species may be distinguished as follows :-

A. With a coloured plate at base of maxilla.

a. Casque curved, rounded on top, circular opening in front.

$a^{\prime}$. Bare skin of face and neck prussian blue,

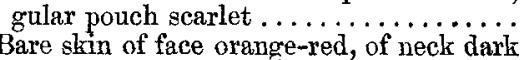

$b^{\prime}$. Bare skin of face orange-red, of neck dark
blue; gular pouch orange .............

1. B. abyssinicus.

B. Without a coloured plate at base of maxilla.
a. Casque nearly straight on top, oval opening in 2. B. pyrrhops.

a. Casque nearly straight on top, oval opening in front; all the bare skin on head and neck yellowish orange or red, with a blue spot at base of mandible ....................

b. Casque compressed laterally, entirely closed in front ; bare skin all blue? .............. 4. B. caffer.

The distribution of the species is somewhat as follows:-

The $B$. abyssinicus is a native of Abyssinia and Sennaar in Eastern Africa. B.pyrrhops is from the region of the Congo, but the extent of its dispersion unknown, although it is proble that this district may be its southern limit, as the $B$. guineensis is found in Angola and the region north of Damaraland; and, lastly, the $B$. caffer is met with in Damaraland and the Zambesi district, and the country lying to the south as far as the Cape. The above distribution can only be given as approximately correct; for our present knowledge does not enable us to define the dispersion of any of the species in the interior of the continent, our acquaintance with most of them having been formed from the specimens obtained at different points comparatively near to the coast-line.

XXIV.-On a Melobesian Form of Foraminifera (Gypsina melobesioides, mihi); and further Observations on Carpenteria monticularis. By H. J. Carter, F.R.S. \&c.

IN my paper on the "Polytremata" ("Annals,' 1876, vol. xvii. p. 185 , pl. xiii. figs. 18,19$)$ I have given a description and figure of a species of Foraminifera having a "Melobesialike" growth, with a striking resemblance to Polytrema in the polygonal reticulation and foraminated interstices presented by the surface. And in my paper "On the Locality of Carpenteria balaniformis" (ib. 1877, vol. xix. p. 215, 
pl. xiii. figs. 19-22) I have described and figured the structure of the spheroidal form of Tinoporus vesicularis, Carp., stating that it was "inexplicable" to me how Dr. Carpenter could have adopted De Montfort's name "Tinoporus" for a genus whose affinities are with Polytrema rather than with Calcarina, of which last De Montfort's Tinoporus baculatus is evidently a species. We have only to place the Red-Sea variety, viz. Calcarina calcar, D'Orb., beside the Philippine Tinoporus baculatus to instantly see the gradation of form between T. baculatus and Calcarina Spengleri, even if the sections of T. baculatus, as I have before stated, did not prove this. The spines on all the Calcarina-like Foraminifera are mere prolongations of the marginal cord and septa combined, both of which are the same in structure, as may be proved by the latter being successively developed (in front of the lastformed chamber) from the marginal cord. Thus the spines, no doubt, possess the same kind of canal-system as that of Operculina, \&c.; but while in Calcarina calcar the marginal cord opposite each chamber sends forth a spine, and the three or four last-formed chambers are visible on the basal side, as in Calcarina Spengleri, there are fewer and larger spines in Tinoporus baculatus, where, too, the three or four last-formed chambers are concealed from view by surface-structure.

Now Tinoporus vesicularis, Carp., has no distinct trochoidal spire of chambers, and nothing like a marginal cord; hence it has no canal-system, nor has it, as I have before stated, the peculiar pseudopodial eanal-system of Polytrema ; in short, it is nothing but a mass of cells growing exogenously in a laminar form from a more or less confused group in the centre, which has no communication with the exterior excepting through the foraminated plates of the respective cells.

Hence, to adopt the name of "Tinoporus" for a totally different genus of Foraminifera like that of Tinoporus vesicularis, Carp., is a mistake, which leading to confusion induces me to propose in its stead that of "Gypsina," whence we get Gypsina vesicularis, Carp., with the spheroidal variety illustrated in my paper of $1877^{(}(\vec{l} . c$.$) .$

This brings us to Gypsina melobesioides, which is but my Polytrema planum in a more extended form. Hitherto all the Foraminifera have been characterized by their individuality. Whole beds of Operculina and Globigerina respectively, extending for many square miles together, present nothing beyond single and separate individuals of these two genera as plentiful and distinct as grains of sand; but in Gypsina melobesioides they are all united together into a continuous incrustration extending over several square inches; in fact 
my Polytrema planum, which in name now becomes quite as inappropriate as "Tinoporus," must also be suppressed for Gypsina melobesioides, since it is but a small specimen of the latter, and no Polytrema at all, as the sequel will show.

There is a very common sponge to be obtained from the shores of the Mauritius, which evidently belongs to my group "Otahitica," but differs from the typical structure of the Psammonemata in being composed of simple fibre coated, instead of "cored," with foreign bodies, wherefore a subgroup will have to be formed for this and the like sponges, which might be termed "Sarcopsammosa." Be this as it may, this sponge is found growing on old coral detritus, from a point, which, increasing in size, soon divides into several roundish stems, each of which becomes compressed, and, again dividing, anastomoses with the neighbouring branches, finally terminating in thin, spatuliform, leafy expansions, each of which is surrounded by a somewhat inflated margin. The surface of the branches thus flattened and lacinulated is traversed on each side by a superficial vein-work or reticulation, which is the excretory canal-system; and the whole thus presents the character of the well-known Spongia othahetica of Solander and Ellis, whose colour, when dry and shore-washed, is whitish yellow, like that of cream. For this sponge and its like I would propose the generic name of "Mauricea," and for the species M. lacinulosa.

Like many other sponges it is frequently more or less infested by small parasitic Balani, which, ensconced in little round processes of sponge substance open at the summit, are supplied from the sponge itself and more or less scattered over its branches; while the stems are as often beset with Polytrema, Planorbulina, and worm-tubes.

It is these stems which are covered in the present instance with Gypsinn melobesioides, continuously, to the extent of three inches from the base. There are 8-10 stems, averaging in their round part a quarter of an inch in diameter, and in their flattened or compressed form above about half an inch in their longest diameter. The thickest part of the incrustation, which has very much the appearance of the white saccharine layer spread over bridecakes (hence the name Gypsina), but with a faint bluish tint like that of snow, owing to the crystalline transparency of its cell-structure, is about one fortyeighth of an inch; and the number of layers of which this is composed varies from ten to twenty. I need not go into the minute structure of Gypsina melobesioides, which is precisely the same as that of Polytrema planum and the spheroidal variety of Tinoporus vesicularis, to which I have alluded- 
excepting that the aperture pointed out conjecturally in the former belonged to another animal, as no such thing exists in the specimen of Gypsina melobesioides under consideration, where the cavities of the cells are, as usual, lined by sarcode (assuming a dark brown colour when dry), but communicate with the exterior in no other way than that mentioned, viz. through the foraminated plates of the cells.

In its mode of extension Gypsina melobesioides is very like Melobesia lichenoides, spreading under a thallaceous form with a thin margin; but it is easily distinguished from Melobesia by the closed cells of the latter, and especially by the conceptacles, if there are any present. It is also, in appearance, very like the white crust of a Gorgonia, from which it is also easily distinguished by the latter being composed of the usual form of spino-tuberculated spicule.

Thus we have at last come upon a thallophytic species of Foraminifera, whose cells being foraminated instead of closed points out the usual distinction between animals and plants, while, like many other lower animals, it still presents a plantlike form. Where are we to look for the "single nucleus" here?

There is a fossil variety of Gypsina from the Miocene of Jamaica, of which specimens have been submitted to me for examination by Mr. H. B. Brady, who, following Dr. Carpenter's nomenclature, has called it "Tinoporus pilaris" (Survey Mem. Geol. Jamaica, pt. ii., West-Indian Survey, p. 334). This does not appear to differ in any way from the living spheroidal variety except in its greater size, the largest sent being just one sixth of an inch in diameter.

\section{Carpenteria monticularis.}

With reference to my communication "On the Branched Form of the Apertural Prolongation from the Summit of Carpenteria monticularis" ("Annals,' 1877, vol. xx. p. 68), I might further observe that Squamulina scopula and its variety ramosa ('Annals,' 1870, vol. v. p. 309, pl. iv., \& p. 389) appear to me to be the arenaceous representatives of the Carpenterioe. Like Carpenteria they have a multilocular conical base, each utricle of which opens at the summit into a common tube, that is prolonged upwards into a single or branched form, according to the species ; while the extremities of the branches are beset with projecting spicules, pincushionlike, which are often simulated by the accumulation of spicules in the free ends of the branches both of Carpenteria and 
Polytrema. For Oculina rosea, in the paper first mentioned, read Stylaster sanguineus.

I have also lately found pieces of coral-detritus rock both from Jamaica and the Mauritius, almost covered with fragments of Polytrema miniaceum and Carpenteria utricularis, mixed together indiscriminately, thus presenting respectively in their broken summits a very similar appearance, especially where each utricle of the Carpenteria (which is often the case) appears to have been provided with its own branched tubular prolongation.

\section{XXV.-On a Fossit Species of Sarcohexactinellid Sponge} allied to Hyalonema. By H. J. CarTer, F.R.S. \&c.

ABout the 23rd of June last I had the pleasure to receive from Mr. James Thomson, F.G.S. \&c., of Glasgow, for delineation and description, if thought desirable, a box of fossils from the Carboniferous rocks of Scotland, which "for many years" Mr. Thomson had regarded as belonging to the sponges; and among these is a fragment of rock bearing 4-5 inches of the anchoring lash of spicules respectively of two specimens of apparently the same sarcohexactinellid sponge, which $\mathrm{Mr}$. Thomson views provisionally as having belonged to a "Hyalonema." Besides these there are other specimens of this kind mixed up with sexradiate spicules of various forms; but particularly a fragment where some of these spicules are evidently nearly in situ, which leaves no doubt in my mind that this was a portion of the body of a sarcohexactinellid sponge.

I had, through the great kindness of Dr. J. Millar, become possessed, about a year since, of some of these hexactinellid spicules, as well as fragments of the linear spicules, which I now find to have come from anchoring ones similar to those of the "lash" just mentioned; and these were of the same kind as those exhibited before the British Association at Glasgow last year, where they were called "Acanthaspongia Smithii."

The name of Acanthaspongia siluriensis was proposed by $M^{\prime}$ Coy for the fossil remains of a sponge in the collection of Mr. R. Griffith, F.G.S., obtained from the sandstone of Cong, county Galway; and the specimen (for there is no figure of it) is described ('Synopsis of the Silurian Foss. of Ireland,' p. 67,1846 ) as consisting of " a lengthened oval mass, about two inches long and three fourths of an inch wide, of crowded 